\title{
Communication
}

[Comunicação]

\section{Transrectal endoscopy with three different techniques of rectal suture associate: NOTES survival study with liver biopsy in a swine model}

[Endoscopia transretal para biópsia hepática associada com três diferentes técnicas de sutura retal: estudo da NOTES em modelo experimental suíno]

\author{
A.B. Trindade ${ }^{1}$, C.A.C. Beck ${ }^{1}$, M.W. Ataíde ${ }^{1}$, F. Schiochet ${ }^{1}$, D.G. Gerardi ${ }^{1}$, M.V. Brun ${ }^{2}$, D. Driemeier ${ }^{1}$, \\ P. Zlotowski ${ }^{1}$, M.R.I. Cardoso ${ }^{1}$, E.O. Cirne-Lima ${ }^{1}$, E.A. Contesini ${ }^{1}$ \\ ${ }^{1}$ Universidade Federal do Rio Grande do Sul - UFRGS - Porto Alegre, RS \\ ${ }^{2}$ Universidade Federal de Santa Maria - UFSM - Santa Maria, RS
}

Natural Orifice Transluminal Endoscopic Surgery (NOTES) is a surgical technique produced from combination of endoscopy and laparoscopy to diagnose and treat abdominal diseases, characterized by absence of abdominal incisions (Seid et al., 2008). The NOTES approach has several proposed benefits including potentially decreased abdominal pain, wound infections and hernia formation (Seid et al., 2008; Shin and Kaloo, 2009). The most common routes for NOTES are transvaginal and transoral/transgastric; however, the viability of transurethral, transcolonic and transrectal routes have been studied (Seid et al., 2008; Bazzi et al., 2011).

The transcolonic and transrectal approaches represent promising methods for NOTES procedures and their main advantages over the other routes are: the fast visualization of the abdominal cavity, a better reach and stability of the endoscope inside the abdomen and, particularly, the origination of a bigger orifice to remove tissue or mass specimens. On the other hand, among the most important requirements of this procedure is the safe closure of the viscera that gives access to the abdominal cavity and the adequate healing, since any extravasations of fecal content to the cavity overcomes all the advantages of this surgical approach (Oliveira and Alvarenga, 1998; Sood et al., 2011).

Therefore, this work aimed at evaluating three different techniques of rectal suture in a swine model subjected to transrectal NOTES for liver biopsy and its clinical and hematological repercussions.

All the procedures were conducted at the Faculty of Veterinary Medicine at the Universidade Federal do Rio Grande do Sul (UFRGS), in accordance with the standards issued by the ethics and research commitee of the same university, under protocol number 23376.

Three 120 days old swines were used in the experiment - two females and one male, weighting $40 \pm 5 \mathrm{~kg}$. All animals were restricted from food for30 hour. The bowel preparation included the administration of $0.23 \mathrm{mg} \cdot \mathrm{kg}^{-1}$, bisacodyl and $12 \mathrm{mg} \cdot \mathrm{kg}^{-1}$ of mannitol $20 \%$, both per oral 48 and 24 hours prior to the surgical procedure. The animals were first sedated with intramuscular dose of a mixture containing $15 \mathrm{mg} . \mathrm{kg}^{-1}$ ketamine, $1 \mathrm{mg} . \mathrm{kg}^{-1}$ of midazolam and $3 \mathrm{mg} \cdot \mathrm{kg}^{-1}$ of meperidine. Anesthesia was induced with intravenous (IV) dose of $5 \mathrm{mg} \cdot \mathrm{kg}^{-1}$ of propofol. After endotracheal intubation, anesthesia was maintained with isoflurane, 1-5\%, inhaled. The animals were positioned in left lateral decubitus. The rectum was cleaned with mechanically emptied, intestinal washing with $500 \mathrm{~mL}$ of polyvinylpyrrolidone (PVP-I) $0.1 \%$ and $140 \mathrm{~mL}$ fleet enemas.

The abdominal cavity was insuflated using a Veress needle with medicinal $\mathrm{CO}_{2}$ (2L. $\mathrm{min}^{-1}$, pressure kept at $12 \mathrm{mmHg}$ ). The rectum was

Recebido em 7 de agosto de 2014

Aceito em 8 de maio de 2015

E-mail: anelisebt@yahoo.com.br 
pulled out and three repair points were inserted with mononylon wire 3-0. Under direct visualization, a $3 \mathrm{~cm}$ transverse incision was made, $5 \mathrm{~cm}$ distant from the anal sphincter. A flexible colonoscope (Pentax $®$ ) with $14 \mathrm{~mm}$ diameter and $150 \mathrm{~cm}$ length was, then, inserted through the anus into the rectal incision until reaching the abdominal cavity. The animals were positioned in dorsal decubitus and in Trendelenburg position seeking to keep the ventral wall of the abdominal cavity in focus, so the abdominal visceras could be located with special attention being paid to the hepatic lobes. Sterile biopsy forceps with $2 \mathrm{~mm}$ diameter were introduced through the working channels to grasp and pull a hepatic fragment collected in the edge of the left lateral liver lobe. The specimen was immediately immersed in transport medium with brain heart infusion (BHI) broth, for microbiological analysis (Quinn, 2011).

The rectal wound was closed under direct visualization using conventional instruments. Each animal received a different kind of suture. The first swine (number 1) received a suture in two planes: simple isolated points and running 30 inabsorbable suture. Swine number 2 received a polypropylene synthetic mesh measuring $3 \times 3 \mathrm{~cm}$ that was accommodated in the serous region and sutured to it in simple isolated points with polyglactin 910 wire number 3-0. Soon after that, a simple continuous suture was done on the submucosal layer with the same suture wire. In the third swine, it was used bovine pericardium membrane conserved in $98 \%$ glycerin; this membrane was removed of glycerin and immersed in $\mathrm{NaCl} 0.9 \%$ solution for 15 minutes. After then, it was molded $(3 \mathrm{~cm} \times 3 \mathrm{~cm})$ and accommodated in the serous portion of the rectum and sutured with polyglactin $9103-0$, in simple isolated pattern. Finally, this animal received a simple continuous pattern suture in the submucosa region with the same wire.

After the surgical procedure, an abdominocentesis was performed in order to withdraw the remaining abdominal medical $\mathrm{CO}_{2}$. During the postoperative, the animals were given metronidazole $10 \mathrm{mg} \cdot \mathrm{kg}^{-1}$, bid, cephalexin $13 \mathrm{mg} \cdot \mathrm{kg}^{-1}$ bid, for five days, meloxicam $0,05 \mathrm{mg} \cdot \mathrm{kg}^{-1}$, bid, and tramadol hydrochloride ${ }^{\mathrm{n}}$ $2,5 \mathrm{mg} . \mathrm{kg}^{-1}$ bid, both for three days. All the drugs postoperative were given orally.
For the hematologic evaluation, blood was collected in two occasions - before the surgical procedure and on the seventh day postoperatively. During the first 20 days of the postoperative period, the animals were evaluated daily regarding abdominal pain on palpation, dyschezia, hematochezia, appetite and water ingestion, in addition to the evaluation of mucosa and rectal temperature.

The euthanasia was conducted at 20 days after the postoperative. For that, initial sedation was achieved using tiletamine associated with zolazepam $\left(2 \mathrm{mg} \cdot \mathrm{kg}^{-1}, \mathrm{IM}\right)$, morphine $\left(0.3 \mathrm{mg} . \mathrm{kg}^{-}\right.$ 1, IM), sodium thiopental $2.5 \%$ (approximate dosage $30 \mathrm{mg} \mathrm{kg}^{-1}$, IV) and induction of cardiorespiratory arrest with potassium chloride.

During the necropsy, liver and rectal scars, the presence of dehiscence of the rectal suture, abdominal adherences and peritonitis signs were evaluated macroscopically (Figure 1). The three samples that had been fixed in $10 \%$ buffered formalin were set in paraffin blocks and sectioned into $3 \mu \mathrm{m}$ slices. They were later stained for microscopic assessment using hematoxylin-eosin (HE). A hepatic fragment was collected for microbiologic analysis. The bacterial identification was based on colony morphology, microscopic morphology and biochemical tests (Quinn, 2011).

For the three swines subjected to the liver biopsy procedure via transrectal NOTES, the possibility of conducting the entire surgical procedure without any trans and postoperative intercurrences was verified.

The absence of abdominal adherences and signs of peritonitis during the necropsy procedure suggest that, among other features, the technique applied promoted a proper bowel preparation, leading to a reduction of the rectal content and the consequent reduction of the bacterial count that could be carried into the cavity and cause inflammatory signs preceding peritonitis. Other factors that could justify the absence of adherences in the animals subjected to this study are the absence of abdominal incision, since most of the adherences are situated at the abdominal access (Shin and Kaloo, 2009), added to the type of procedure associated to the few manipulations. 


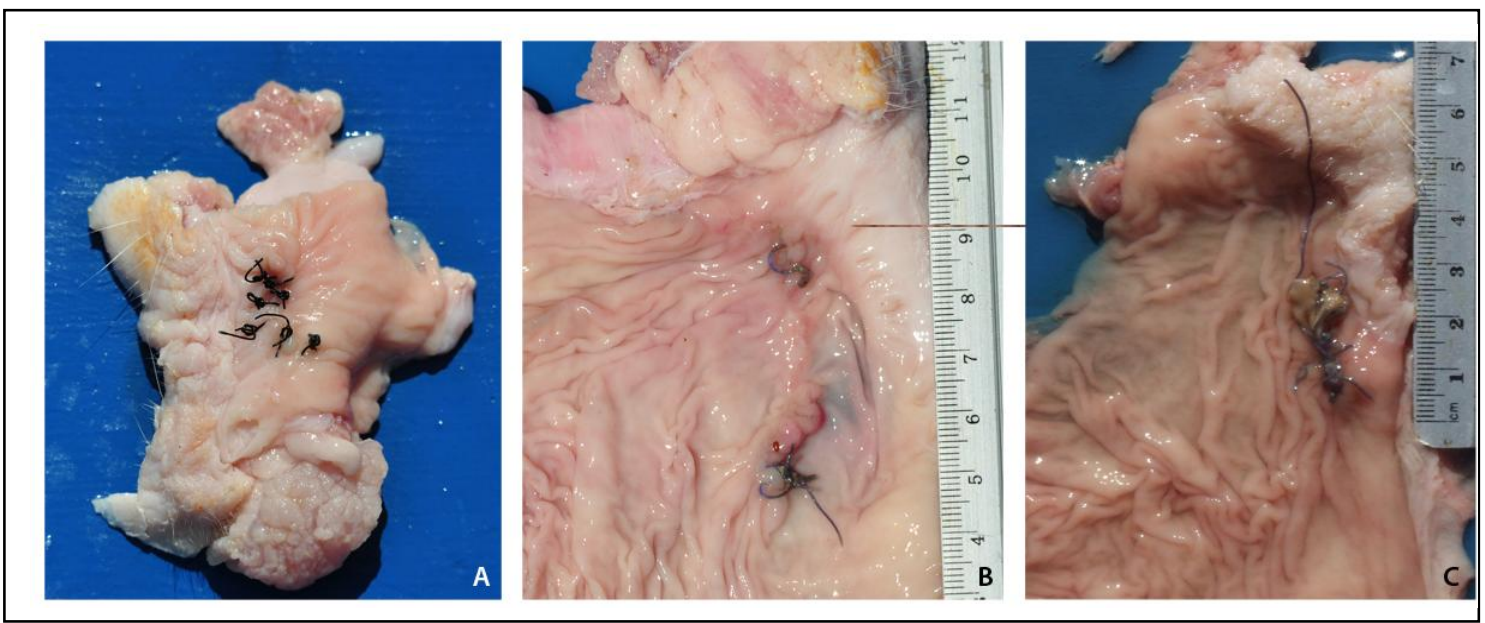

Figure 1. Macroscopic appearance of the rectal suture in swines that underwent transrectal NOTES site. (A) Suture simple isolated followed by simple continuous suture with inabsorbable suture. (B) Polypropylene synthetic mesh accommodated in the serous region and after that, a simple continuous suture was done on the submucosal layer with the same suture wire. (C) Bovine pericardium membrane conserved in $98 \%$ glycerin was accommodated in the serous portion of the rectum and followed by simple continuous pattern suture in the submucosa region.

In the microscopic assessment of swines number 1 and 2, connective tissue proliferation was observed without inflammatory reaction, indicating advanced stage of healing (Kuo et al., 2012). Conversely, swine number 3 presented marked pyogranulomatous inflammation with proliferation of giant cells within the connective tissue on both submucosa and muscular layers and severe ulceration of the mucosa, suggesting delay on the healing process. In this animal, the placement of the biological membrane involved a region of easy access to contamination. Thus, the increased cellular response and extended inflammatory phase may have been favored by the implant material and presence of microorganisms, like the collagenase-producing bacteria (Oliveira; Alvarenga, 1998).

The NOTES is indicated for patients who have large scars, necrosis or abdominal burns and require abdominal surgery (Della Flora et al., 2007; Vosburgh and Estépar, 2007). The initial results of this study could be utile showing some results associated with transrectal reconstruction of NOTES in swine, regardless the initial indication for this approach. In this way, hepatic biopsy was performed together to simulate some visceral approach associated with organic biopsy. Of course, this approach will not be indicated when some more minimally invasive technique of hepatic biopsy could be performed.
One advantage of the transrectal access observed in this work is the possibility of performing the approach incision on the exposed portion of the viscera, therefore, under direct visualization, similarly to what was done by Bazzi et al. (2011). This access allows the use of conventional sutures and/or rectal reinforcements with meshes or membranes, preventing the need for specialized devices.

Regarding the hematologic alterations, only swine number 1 showed significant increase in the lymphocytes and total leukocytes count, but their values remained within the physiological ranges for the species (Prado, 2004). Studies demonstrate that acute psychological stress affects lymphocyte circulation and two phases are recognized after catecholamine liberation: a quick (<30 min) mobilization of lymphocytes, followed by decreasing lymphocyte numbers (Benschop et al., 1996). However, it is worth stressing that this animal was the only male among two other females, showing dominant behavior. Thus, it is reasonable to assume that this alteration was due to the contention stress.

The presence exclusively of Staphylococcus spp. in the liver fragment collected during the surgical procedure can be due to translocation from the skin with the insertion of the endoscope or biopsy forceps. This bacteria is commonly found 
in normal skin microbiota (Scott et al., 2001; Sood et al., 2011). Although antisepsis of the perineal area had been performed, the mucocutaneous junction has small recesses that may have hindered adequate bacteria removal. In conclusion, our results showed that transrectal NOTES procedure for liver biopsy in this swine model is feasible and was accompanied by fast recovery without clinical and hematologic changes. The use of biological membrane for rectal closure delayed wound healing compared to the conventional suture and the polypropylene mesh.

Keywords: endoscopic surgery, endoscopy, rectal access, rectal suture

\section{RESUMO}

A cirurgia endoscópica por orifícios naturais (NOTES) representa um novo conceito de cirurgia, caracterizada por ausência de incisões abdominais. Os acessos mais comumente usados são o transvaginal e o transgástrico. Entretanto, as rotas transcolônica e transretal representam alternativas promissoras. O presente estudo objetiva avaliar três diferentes técnicas de sutura retal em três suínos submetidos a NOTES transretal para biópsia hepática, avaliando-se concomitantemente as repercussões clínicas e hematológicas. Sob anestesia geral, foi realizada uma incisão transversal no reto para a passagem do endoscópio até a cavidade abdominal em todos os animais para a realização da biópsia hepática. Cada animal recebeu um tipo de sutura retal: sutura em dois planos; reforço com tela de polipropileno ou reforço com membrana de pericárdio bovino. A NOTES transretal em modelo experimental suíno não apresentou implicações clínicas e hematológicas importantes, o que demonstra um acesso alternativo para biópsia hepática. Nenhum animal apresentou sinais de peritonite, aderências ou deiscência de pontos. $O$ uso de reforço com pericárdio bovino para a sutura retal apresenta um atraso na cicatrização quando comparado com a sutura convencional ou com o uso de tela de polipropileno.

Palavras-chave: cirurgia endoscópica, endoscopia, acesso retal, sutura retal

\section{REFERENCES}

BAZZI, W.M.; WAGNER, O.; STROUP, S.P. et al. Transrectal hybrid natural orifice transluminal endoscopic surgery (NOTES) nephrectomy in a porcine model. Urology, v.77, p.518-523, 2011.

BENSCHOP, R.J.; RODRIGUEZ-FEUERHAHN, M.; SCHEDLOWSKI, M. Catecholamine-induced leukocytosis: early observations, current research and future directions. Brain Behav Immun., v.10, p.77-91, 1996.

DELLA FLORA, E.A. Natural orifice translumenal endoscopic surgery (NOTES) for intra-abdominal surgery. Stepney: Australian Safety and Efficacy Register of New Interventional Procedures -Surgical (ASERNIPS). 2007. (Report number, 62).

KUO, Y.R.; CHEN, C.C.; GOTO, S. et al. Immunoimodulatory effects of bone-marrow mesenchymal stem cells in a swine hemi-facial allotransplantation model. PLOS ONE., v.7, p. 110, 2012.
OLIVEIRA, V.A.; ALVARENGA, J. Membrana amniótica preservada em glicerina no reparo de feridas cutâneas de membros locomotores de equinos. Cienc. Rural., v.28, p.623-28, 1998.

PRADO, A.M.R.B. Valores hematimétricos normais em suínos Sus Scrofa dom. Lineu, 1758, das raças Landrace e Large White no Paraná, Brasil. Rev. Acad. Ciênc. Agrár. Amb., v.2, p.6580, 2004.

QUINN, P.J.; MARKEY, B.K.; LEONARD, F.C. et al. Veterinary Microbiology and Microbial Disease. Iowa: Wiley-Blackwell, 2011. p. 912.

SEID, V.E.; ARAUJO, E.A.; CARAVATTO, P.P.P. et al. NOTES: presente e futuro - uma breve revisão. Einstein, v.6, p. 99-101, 2008.

SHIN, E.J.; KALLOO, N.A. Transcolonic NOTES: Current experience and potential implications for urologic applications. $J$. Endourol., v.23, p.743-746, 2009. 
SCOTT, D.W.; MILLER, W.H.; GRIFFIN, C.E. Bacterial skin disease. In: SCOTT, D.W.; MILLER, W.H.; GRIFFIN, C.E. Small Animal Dermatology. Pennsylvania: Saunders, 2001. p.274-335.

SOOD, V.; COLLINS, C.; HARRINGTON, S. et al. Transgastric endoscopic pneumoperitoneum versus laparoscopy: effects on host systemic and peritoneal inflammatory resposes in a porcine model. Surg Endosc., v.26, p.189-196, 2011.
VOSBURGH, K.G.; ESTEPAR, R.S.J. Natural orifice transluminal endoscopic surgery (NOTES): an opportunity for argmented reality guidance. Stud Health Technol Inform., v.125, p.485-490, 2007. 